\title{
Isolat EGCG Teh Hijau Klon GMB4 Menurunkan Ekspresi Protein Faktor Transkripsi C/EBP $\alpha$ dan Kadar Leptin pada Kultur Sel Preadiposit Visceral Tikus
}

\section{EGCG Green Tea GMB4 Clone Isolate Decrease Transcription Factor Protein C/EBPa Expression and Leptin Level on Preadipocytes Culture Cell of Rat Visceral}

\author{
Analis W Wardhana ${ }^{1}$, Retty Ratnawati $i^{2}$, Hidayat Suyuti $i^{3}$ \\ ${ }^{1}$ Program Studi Kedokteran Hewan Universitas Brawijaya Malang \\ ${ }^{2}$ Laboratorium Ilmu Faal Fakultas Kedokteran Universitas Brawijaya Malang \\ ${ }^{3}$ Laboratorium Biokimia-Biomolekuler Fakultas Kedokteran Universitas Brawijaya Malang
}

\begin{abstract}
ABSTRAK
Isolat golongan senyawa katekin teh hijau (Camelia sinensis) klon GMB4 dapat dikembangkan sebagai agen terapeutik potensial untuk obesitas. Penelitian ini ditujukan untuk mengetahui efek isolat EGCG teh hijau klon GMB4 terhadap ekspresi protein faktor transkripsi C/EBP $\alpha$ dan terhadap kadar protein leptin pada kultur preadiposit viseral tikus. Metode ELISA digunakan untuk mengukur kadar leptin dan immunositokimia untuk ekspresi protein faktor transkripsi C/EBPa. Kultur sel preadiposit viseral tikus yang diisolasi dari tikus Rattus norvegicus Wistar yang ditumbuhkan dalam medium adipogenik dan selanjutnya dipapar dengan isolat golongan senyawa katekin teh hijau (Camelia sinensis) klon GMB4 dengan konsentrasi 0, $50 \mu \mathrm{M}, 100 \mu \mathrm{M}$, dan $200 \mu \mathrm{M}$. Ekspresi C/EBP $\alpha$ paling rendah terdapat pada konsentrasi isolat EGCG $200 \mu \mathrm{M}$. Kadar leptin menurun seiring dengan dosis EGCG yang dinaikkan, sehingga kadar leptin berbanding terbalik dengan dosis EGCG. Kadar leptin terendah pada pemaparan EGCG dengan dosis $200 \mu \mathrm{M}$. Dapat disimpulkan bahwa isolat EGCG teh hijau klon GMB4 secara signifikan dapat menurunkan ekspresi protein faktor transkripsi C/EBP $\alpha$ pada kultur preadiposit viseral tikus pada konsentrasi $200 \mu \mathrm{M}$ dan menurunkan kadar protein leptin pada kultur preadiposit viseral tikus pada konsentrasi $50 \mu \mathrm{M}, 100 \mu \mathrm{M}$, dan $200 \mu \mathrm{M}$.
\end{abstract}

Kata Kunci: C/EBP $\alpha, E G C G, G M B 4$, leptin, sel preadiposit, teh hijau

ABSTRACT

Catechin compound of green tea (Camelia sinensis) GMB 4 clone isolate can be developed as potential theurapetic agent for obesity. The research aim to determine the effect of EGCG green tea GMB4 clone isolate to transcription factor protein $C / E B P \alpha$ expression and level of leptin protein on preadipocytes cultur of rat visceral. ELISA method used to measure the leptin level and immunohistochemistry to count the trascription factor protein C/EBP $\alpha$ expression. Culture of Preadipocytes cell of rat visceral isolated from Rattus norvegicus wistar grown in the medium of adipogenic and exposed with green tea catechin compound (Camelia sinensis) from GMB4 clone concentrate dose 0, $50 \mu \mathrm{M}, 100 \mu \mathrm{M}$, and $200 \mu \mathrm{M}$. The lowest C/EBP $\alpha$ expression found in the EGCG isolate concentration of $200 \mu \mathrm{M}$. Leptin level decrease as the raising dose of EGCG. The lowest leptin level found in EGCG dose $200 \mu \mathrm{M}$. The research concluded that EGCG green tea isolate of GMB4 clone significantly decrease transription factor protein C/EBP $\alpha$ on the culture of visceral preadipocytes rat on $200 \mu M$ concentration and decrease leptin protein level on concentration of $50 \mu \mathrm{M}, 100 \mu \mathrm{M}$, dan $200 \mu \mathrm{M}$.

Keywords: C/EBP $\alpha, E G C G, G M B 4$, green tea, leptin, preadipocytes cell

Jurnal Kedokteran Brawijaya, Vol. 27, No. 4, Agustus 2013; Korespondensi: Analis W Wardhana. Program Studi Kedokteran Hewan Universitas Brawijaya Malang, JI. MT Haryono No. 169 Malang Tel. (0341) 573642 Email: analis_wardhana@yahoo.com 


\section{PENDAHULUAN}

Obesitas merupakan salah satu masalah kesehatan yang menjadi perhatian karena berhubungan dengan sejumlah komplikasi medis yang menyebabkan tingginya angka morbiditas dan mortalitas (1). Obesitas terjadi jika Body Mass Index (BMI) menunjukkan $\geq 30 \mathrm{~kg} / \mathrm{m}^{2}$. Obesitas timbul akibat ketidakseimbangan antara energi yang masuk dengan energi yang dikeluarkan. Kelebihan energi disimpan dalam jaringan adiposa dalam bentuk trigliserida.

Sel adiposit sekarang tidak lagi dianggap sebagai tempat penyimpanan kelebihan energi dalam bentuk trigliserida yang bersifat pasif, tetapi merupakan sel yang secara aktif meregulasi pathway yang bertanggung jawab terhadap keseimbangan energi yang aktifitasnya dikontrol oleh jaringan hormonal dan sinyal neuronal yang kompleks. Sel adiposit mensekresi messenger kimia diantaranya adalah leptin (2). Leptin disekresi terutama oleh sel adiposit dan merupakan salah satu dari lebih 50 adipositokin yang teridentifikasi dan terlibat dalam sinyal hormonal pada jaringan adiposit leptin merupakan faktor utama yang menentukan regulasi berat badan, metabolisme energi dan terjadinya obesitas serta kelainan yang menyertainya pada manusia (3). Leptin dikenal sebagai hormon yang digunakan sebagai marker untuk obesitas (4).

Leptin merupakan produk yang dihasilkan oleh obese (ob) gene, dan promoter ob gen tersebut diaktivasi oleh protein faktor transkripsi C/EBP $\alpha$ (CCAT/enhancer binding protein $\alpha$ ) (5). Protein C/EBP $\alpha$ mempunyai fungsi yang sangat penting pada ekspresi ob gen, baik pada sel preadiposit dan adiposit (6). Protein C/EBP $\alpha$ meningkatkan ekspresi leptin in vivo dan merupakan satusatunya prediktor dari ekspresi leptin pada jaringan ekstraperitoneal (7). Sebagai salah satu faktor transkripsi pada tahap akhir diferensiasi adiposit C/EBP $\alpha$ dapat dihambat oleh katekins di dalam teh hijau yang dapat mencegah obesitas.

Epigallocathecin gallate (EGCG) adalah katekin yang paling tinggi kandungannya pada teh hijau, kira-kira sebesar 35\% dari jumlah katekins dan merupakan agen anti-obesigenik paling potensial. Lembaga Penelitian Teh dan Kina Gambung telah berhasil mengembangkan klon tanaman teh hijau yaitu klon GMB4 dengan kadar katekins yang lebih tinggi (17\%) daripada tanaman teh lainnya (8). Studi Herin membuktikan bahwa EGCG pada dosis 8 $\mathrm{mg} / \mathrm{kg}$ BB the hijau klon GMB4 mampu menghambat resistensi insulin dengan penurunan kadar SREBP-1 jaringan adiposa dan lemak viseral (9). Hasil penelitian Ratnawati (2010) secara in vivo, Isolat Epigallocatechin gallate (EGCG) dari teh hijau klon GMB4 mampu menurunkan C/EBP- $\alpha$ dan leptin jaringan adiposa pada tikus galur Wistar betina yang diberikan Diet Tinggi Lemak, namun penelitian secara in vitro belum pernah dilakukan. Penelitian ini dilakukan untuk melihat efek isolat EGCG teh hijau klon GMB4 secara in vitro pada kultur sel preadiposit tikus terhadap ekspresi protein faktor transkripsi C/EBP- $\alpha$ dan kadar leptin untuk mengetahui potensi yang dimiliki oleh EGCG teh hijau klon GMB4 sehingga bisa memanfaatkan plasma nutfah asli Indonesia sebagai alternatif penangulangan obesitas.

\section{METODE}

\section{Isolasi Sel dan Kultur Sel}

Depo jaringan lemak (priepididimal, retroperitoneal, atau subkutan) disayat dalam kondisi steril dan dibebaskan semaksimal mungkin dari kapiler darah, kemudian dimasukkan ke dalam media tranfer. Jaringan dicuci dua kali dengan dPBS, kemudian dicuci sekali lagi dengan media kultur tanpa serum FBS, pada tahap ini jaringan lemak dicacah kecil-kecil. Jaringan diambil menggunakan pinset dan dimasukkan dalam tabung $15 \mathrm{ml}$ yang berisi larutan kolagenase tipe I (Sigma, USA). Jaringan diinkubasi dalam waterbath shaker selama 1-2 jam pada suhu $37^{\circ} \mathrm{C}$, kemudian jaringan disentrifus pada kecepatan $1000 \mathrm{rpm}$ selama 7 menit. Supernatan dibuang dan pelet diambil kemudian ditambahkan media serum free dan dihomogenisasi dan dilakukan sentrifugasi pada kecepatan $1000 \mathrm{rpm}$ selama 7 menit. Selanjutnya supernatan dibuang dan pelet diambil kemudian ditambahkan media yang mengandung FBS 10\% dan dihomogenisasi dilakukan penanaman pada flask atau plate kultur, kemudian diinkubasi pada suhu atmosfir lembab mengandung $5 \% \mathrm{CO}_{2}$ suhu $37^{\circ} \mathrm{C}$ selama 24 jam. Sel dicuci setiap dua hari sekali (9).

\section{Stimulasi Diferensiasi Adiposit}

Setelah mencapai preconfluent (tumbuh hampir merata pada media kultur), sel preadiposit tikus ditumbuhkan dalam media adipogenik (DMEM/F12 dengan ditambahkan 66nM insulin, $100 \mathrm{nM}$ dexamethasone, 0,2 $\mathrm{mM}$ IBMX dan $10 \mu \mathrm{g} / \mathrm{ml}$ TZD) untuk diferensiasi sel. Suspensi sel ditumbuhkan di atas cover glass pada culture plate dengan inkubasi pada suhu $37^{\circ} \mathrm{C}, 5 \% \mathrm{CO}_{2}$ selama 24 jam. Sel dicuci setiap 3 hari sekali (10).

Perlakuan Isolat Epigallotechin gallate (EGCG) Teh Hijau Klon GMB4

Isolat EGCG merupakan hasil isolasi teh hijau GMB4 Lembaga penelitian Teh dan Kina Gambung, Bandung yang dilakukan di Laboratorium Kimia, FMIPA ITB, Bandung. Setelah preadiposit mengalami preconfluent $70 \%$ maka EGCG dilarutkan dalam medium serum free dan diinkubasi selama 24 jam dengan beberapa konsentrasi yaitu $0 \mu \mathrm{M}$, $50 \mu \mathrm{M}, 100 \mu \mathrm{M}$, dan $200 \mu \mathrm{M}$ masing-masing 6 replikasi. Setelah diinkubasi 24 jam dilakukan pengukuran kadar leptin pada media dengan metode ELISA dan ekspresi protein faktor transkripsi $\mathrm{C} / \mathrm{EBP} \alpha$ diamati dengan immunositokimia $(8,11)$.

Pengukuran Kadar Leptin melalui Metode ELISA (Enzyme Linked Immunosorbent Assay)

Protokol pengukuran leptin menggunakan panduan manual kit ELISA dari Cusabio Biotech CO.Ltd.China. Sampel media sel adiposit dan standar sebanyak $100 \mu \mathrm{L}$ dimasukkan ke dalam sumuran yang telah dicoating dengan anti-leptin poliklonal dan ditutup dengan adhesive strip, selanjutnya diinkubasi selama 2 jam pada suhu $37^{\circ} \mathrm{C}$. Cairan pada tiap sumuran dibuang tanpa dilakukan pembilasan. Pada sumuran ditambahkan $100 \mu \mathrm{L}$ Biotinsecondary Antibody dan diinkubasi selama 1 jam pada suhu $37^{\circ} \mathrm{C}$. Sumuran dicuci dengan wash buffer $200 \mu \mathrm{L}$ sebanyak 3 kali. Selanjutnya ditambahkan HRP-avidin pada setiap sumuran sebanyak $100 \mu \mathrm{L}$ kemudian ditutup dengan adhesive strip dan diinkubasi selama 1 jam pada suhu $37^{\circ} \mathrm{C}$. Sumuran dicuci kembali dengan wash buffer $(200 \mu \mathrm{L})$ 
sebanyak 3 kali. Selanjutnya ditambahkan $90 \mu \mathrm{L}$ TMB substrate pada setiap sumuran dan diinkubasi selama 1030 menit pada suhu $37^{\circ} \mathrm{C}$. Ditambahkan $50 \mu \mathrm{L}$ stop solution pada setiap well dan dibaca pada panjang gelombang $450 \mathrm{~nm}$ dengan ELISA reader.

Pengamatan Ekspresi Protein C/EBP $\alpha$ dengan Immunositokimia

Prosedur Immunositokimia yang digunakan berpedoman pada Dakocytomation Staining kits LSAB 2 System-HRP Code K0673, Denmark, pada masing-masing perlakuan, sel kultur diblock dengan hidrogen peroksida, dan diinkubasi selama $5( \pm 1)$ menit dan kemudian dicuci dengan buffer solution. Sel kultur ditambahkan antibodi primer monoclonal (anti C/EBP $\alpha$, Santa Cruz Biotechnology, USA) atau negative control reagen sampai menutup semua bagian cover slip diinkubasi selama 60 menit, dan kemudian dicuci dengan buffer solution. Sel kultur ditambahkan Link Antibody, dan diinkubasi selama $10( \pm 1)$ menit dan kemudian dicuci dengan buffer solution. Selanjutnya sel kultur ditambah dengan reagen streptavidin, dan diinkubasi selama $10( \pm 1)$ menit kemudian dicuci dengan buffer solution. Sel kultur ditambahkan DAB substrate-Chromogen solution, kemudian diinkubasi 5-10 menit Slide sel kultur dicelupkan pada hematoxylen dan diinkubasi selama 2-5 menit kemudian cuci dengan distilled water. Selanjutnya slide dimasukkan 10 kali ke dalam 0,037ml/L ammonia water, kemudian dicuci dengan distilled water selama 2-5 menit kemudian cover slip diangkat dari plate culture kemudian dilanjutkan tahap monitoring. Dilakukan tahap mounting dengan cara sel diletakkan pada object glass dan ditetesi dengan aqueous-based mounting medium, seperti Faramount atau Gliserol. Selanjutnya, preparat sel tersebut diamati di bawah mikroskop lalu dihitung jumlah sel yang berwarna coklat (merupakan indikator eskpresi dari $C / E B P \alpha$ ). Eskpresi $C / E B P \alpha$ dapat dilihat pada bagian inti sel yang terwarnai dengan warna coklat.

Setelah data dari hasil pengamatan dan pengukuran dikumpulkan, kemudian dilakukan analisis data dengan menggunakan statistik parametrik. Data hasil penelitian akan disajikan dalam mean \pm SD. Data penelitian merupakan data kuantitatif dan kualitatif. Untuk data kuantitatif dianalisis dengan menggunakan software SPSS release 17 menggunakan One-Way ANOVA.

\section{HASIL}

Penelitian ini dilakukan pada bulan Nopember 2010 sampai bulan Maret 2011 di Laboratorium ilmu Faal Fakultas Kedokteran, Universitas Brawijaya, Malang. Penelitian ini merupakan penelitian in vitro dengan menggunakan sel preadiposit yang diisolasi dari tikus Rattus norvegicus Wistar yang ditumbuhkan dalam medium adipogenik dan selanjutnya dipapar dengan isolat EGCG teh hijau klon GMB4 dengan konsentrasi 0, 50 $\mu \mathrm{M}, 100 \mu \mathrm{M}, 200 \mu \mathrm{M}$. Hasil dari kultur perkembangan sel fibroblast like preadipocyte yang ditandai dengan bentukan sel fibroblast menjadi sel adiposit mature yang ditandai dengan pembentukan butiran lemak (Gambar 1).

Ekspresi Protein Faktor Transkripsi C/EBP $\alpha$ Sel preadiposit yang Dipapar dengan Isolat EGCG Teh Hijau Klon GMB4

Untuk mengetahui pengaruh isolat EGCG terhadap ekspresi C/EBP $\alpha$, maka dilakukan pewarnaan imunositokimia yang menggunakan DAB (Diamino Benzidine). Pada hari ke-6 kultur sel fibroblast like

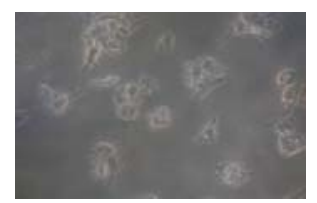

Hari ke-1

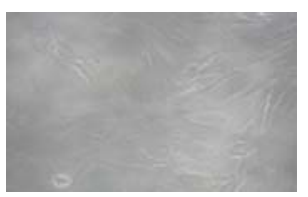

Hari ke -3

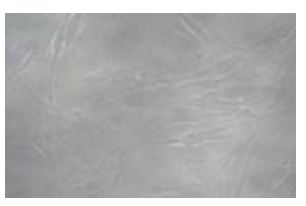

Harike-5

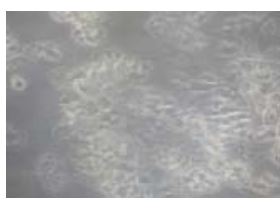

Hari ke-2

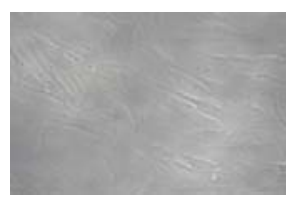

Hari ke-4

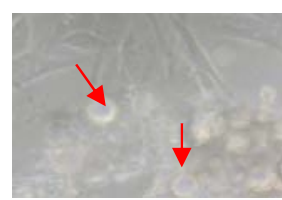

Harike-6
Gambar 1. Perkembangan sel fibroblast like preadipocyte

Keterangan: Perkembangan ditandai dengan pembentukan sel fibroblast yang belum berkembang menjadi sel preadiposit; inkubasi pada sel preadiposit dengan medium diferensiasi dilakukan pada hari ke-5 dan hari ke-6 mulai tampak bentuk butiran lemak (tanda panah merah) (fotomikroskop Ollympus CX31 perbesaran 400x).

preadipocyte diinduksi dengan medium diferensiasi dan dipapar dengan isolat EGCG selama 24 jam, sel yang telah membentuk monolayer dan konfluen dilakukan pewarnaan imunositokimia dan dihitung jumlah sel yang mengekspresikan C/EBP $\alpha$ per 100 sel (Gambar 2).

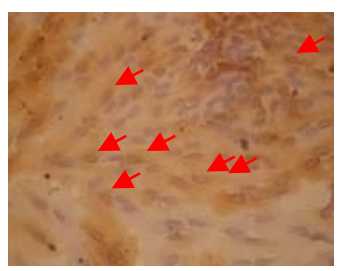

Kontrol

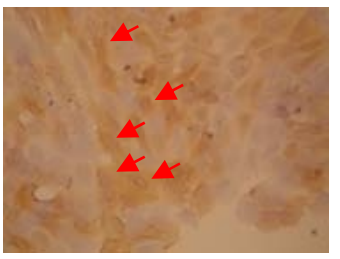

EGCG $100 \mu \mathrm{M}$

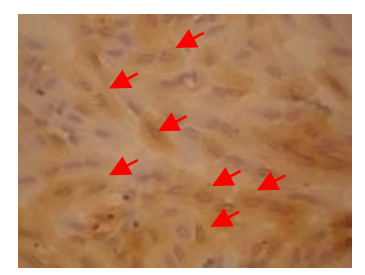

EGCG $50 \mu \mathrm{M}$

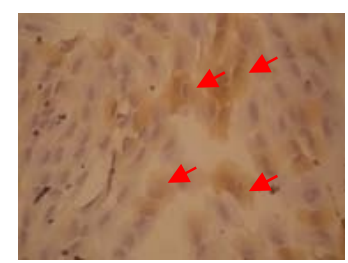

EGCG $200 \mu \mathrm{M}$
Gambar 2. Ekspresi C/EBP $\alpha$ pada sel preadiposit setelah terpapar dengan isolat EGCG teh hijau klon GMB4 selama 24 jam.

Keterangan: Ekspresi C/EBP $\alpha$ (tanda panah merah) paling tinggi terdapat pada kelompok kontrol dan semakin menurun ekspresinya seiring meningkatnya dosis EGCG yang diberikan (fotomikroskop Olympus CX31 perbesaran $400 \mathrm{X}$ )

Ekspresi C/EBP $\alpha$ ditunjukkan dengan warna coklat pada inti sel, dimana ekspresi C/EBP $\alpha$ paling tinggi terlihat pada kelompok kontrol $(75,1667 \pm 11,16094)$. Ekspresi C/EBP $\alpha$ semakin rendah pada dosis isolat EGCG teh hijau klon GMB4 yang semakin tinggi (Tabel 1 ). Ekspresi C/EBP $\alpha$ 
paling rendah terdapat pada konsentrasi isolat EGCG 200 $\mu \mathrm{M}(28,5000 \pm 14,67992)$ yang terlihat dari sediaan apusan sel yang tidak menyerap pewarna $\mathrm{DAB}$, sehingga sel hanya berwarna biru.

Tabel 1. Hasil kuantifikasi ekspresi C/EBP $\alpha$ (sel/100 sel) dengan Analisis One-Way ANOVA

\begin{tabular}{lcc}
\hline Perlakuan & N & $\begin{array}{c}\text { Mean } \pm \text { SD* } \\
\text { p }(<0,05)\end{array}$ \\
\hline Kontrol & 6 & $75,1667 \pm 11,16094\left(\mathrm{~b}^{*}\right.$ \\
EGCG50 $\mu \mathrm{M}$ & 6 & $67,8333 \pm 14,26067\left(\mathrm{~b}^{*}\right.$ \\
EGCG $100 \mu \mathrm{M}$ & 6 & $63,8333 \pm 12,23792\left(\mathrm{~b}^{*}\right.$ \\
EGCG $200 \mu \mathrm{M}$ & 6 & $28,5000 \pm 14,67992\left(\mathrm{a}^{*}\right.$ \\
\hline
\end{tabular}

Keterangan: *Notasi yang berbeda menunjukkan perbedaan yang signifikan

Berdasarkan hasil analisis uji statistik One-Way ANOVA $(\alpha=0,05)$ diketahui ada perbedaan yang signifikan pemaparan isolat EGCG teh hijau klon GMB4 pada beberapa dosis terhadap ekspresi C/EBP $\alpha$ pada sel preadiposit tikus $(p=0,000)$. Hasil pengujian berganda dengan uji Tukey HSD didapatkan bahwa ekspresi C/EBP $\alpha$ pada kelompok kontrol menunjukkan perbedaan yang signifikan dengan kelompok perlakuan yang diberikan isolat EGCG dengan konsentrasi $200 \mu \mathrm{M}(p=0,000)$, kelompok perlakuan konsentrasi $200 \mu \mathrm{M}$ juga berbeda signifikan dengan kelompok perlakuan konsentrasi $50 \mu \mathrm{M}$ $(p=0,000)$ dan kelompok perlakuan konsentrasi $100 \mu \mathrm{M}$ $(p=0,001)$. Antara kelompok kontrol dengan kelompok perlakuan konsentrasi $50 \mu \mathrm{M}$ dan kelompok perlakuan konsentrasi $100 \mu \mathrm{M}$ tidak menunjukkan perbedaan yang signifikan. Hasil ini menunjukkan bahwa pada pemberian isolat EGCG teh hijau klon GMBA dosis 50 dan $100 \mu \mathrm{M}$ belum memberikan penurunan ekspresi C/EBP $\alpha$ yang bermakna dibandingkan kontrol. Penurunan signifikan baru didapatkan pada dosis $200 \mu \mathrm{M}$.

\section{Kadar Leptin Sel Preadiposit yang Dipapar}

Kultur sel preadiposit yang diberi isolat EGCG teh hijau klon menunjukan kadar leptin yang lebih rendah secara signifikan dengan kontrol yang dapat dilihat pada tabel 2 dan gambar 4. Pada konsentrasi EGCG $50 \mu \mathrm{M}$ $(691,665 \pm 40,230)$ diperoleh kadar leptin yang jauh lebih rendah dibandingkan dengan kontrol $(867,313 \pm 14,976)$. Pada konsentrasi EGCG $100 \mu \mathrm{M}(689,43 \pm 101,672)$ diperoleh kadar leptin yang jauh lebih rendah dari kontrol dan pada konsentrasi EGCG $200 \mu \mathrm{M}(516,413 \pm 66,221)$ juga diperoleh kadar leptin yang jauh lebih rendah dibandingkan dengan kontrol. Kadar leptin menurun seiring dengan dosis EGCG yang dinaikkan. Kadar leptin terendah pada pemaparan EGCG dengan dosis $200 \mu \mathrm{M}$.

Tabel 2. Hasil kuantifikasi kadar leptin $(\mathrm{pg} / \mathrm{ml})$ dengan analisis One-Way ANOVA

\begin{tabular}{llc}
\hline \multicolumn{1}{c}{ Perlakuan } & N & $\begin{array}{c}\text { Mean } \pm \text { SD* } \\
\mathbf{p}(<0,05)\end{array}$ \\
\hline Kontrol & 6 & $867,313 \pm 14,976\left(\mathrm{c}^{*}\right.$ \\
EGCG50 $\mu \mathrm{M}$ & 6 & $691,665 \pm 40,230\left(\mathrm{~b}^{*}\right.$ \\
EGCG $100 \mu \mathrm{M}$ & 6 & $689,43 \pm 101,672\left(\mathrm{~b}^{*}\right.$ \\
EGCG $200 \mu \mathrm{M}$ & 6 & $516,413 \pm 66,221\left(\mathrm{a}^{*}\right.$ \\
\hline
\end{tabular}

Keterangan: *Notasi yang berbeda menunjukkan perbedaan yang signifikan
Berdasarkan uji statistik One-Way ANOVA $(\alpha=0,05)$ menunjukkan adanya pengaruh yang signifikan pada pemaparan isolat EGCG terhadap kadar leptin pada media kultur sel preadiposit tikus. Hasil pengujian berganda dengan Tukey HSD didapatkan bahwa terdapat perbedaan kadar leptin medium yang signifikan antara kelompok kontrol dibandingkan dengan kelompok perlakuan konsentrasi $50 \mu \mathrm{M}(p=0,001)$, konsentrasi $100 \mu \mathrm{M}$ $(p=0,001)$ dan perlakuan konsentrasi $200 \mu \mathrm{M}(p=0,000)$. Pada kelompok perlakuan konsentrasi $200 \mu \mathrm{M}$ berbeda signifikan dengan perlakuan konsentrasi $50 \mu \mathrm{M}(p=0,001)$ dan perlakuan konsentrasi $100 \mu \mathrm{M}(\mathrm{p}=0,001)$, sedangkan antar perlakuan konsentrasi $50 \mu \mathrm{M}$ dan perlakuan konsentrasi $100 \mu \mathrm{M}$ tidak ada perbedaan yang signifikan.Hasil ini menunjukkan bahwa pemberian isolate EGCG teh hijau klon GMBA pada semua dosis memberikan kadar leptin yang lebih rendah dibandingkan kontrol. Efek penurunan pada dosis 50 dan $100 \mu \mathrm{M}$ tidak berbeda signifikan. Perbedaan efek yang signifikan ditemukan pada dosis 200 , sehingga dapat disimpulkan dosis merupakan dosis optimum

\section{DISKUSI}

Pada penelitian ini menunjukkan bahwa isolat EGCG dengan dosis $200 \mu \mathrm{M}$ mampu menurunkan ekspresi $\mathrm{C} / \mathrm{EBP} \alpha$ yang berbeda secara signifikan dengan kelompok kontrol dan juga menurunkan kadar leptin pada medium kultur sel preadiposit, baik ekspresi C/EBP $\alpha$ dan kadar leptin menurun seiring dengan peningkatan dosis EGCG yang diberikan.

Hasil penelitian ini sesuai dengan penelitian Lin et al bahwa isolat EGCG dengan dosis $200 \mu \mathrm{M}$ yang merupakan dosis yang mempunyai efek paling kuat, mampu menurunkan lipogenesis dan jumlah sel adiposit dan meningkatkan persentase total sel yang mengalami apoptosis serta menurunkan ukuran butiran lemak (11). C/EBP $\alpha$ merupakan regulator utama adipogenesis dan ekspresi dari gen adipogenik (12). C/EBP $\alpha$ merupakan suatu aktivator transkripsi dari gen leptin (7). Leptin dikenal sebagai hormon yang digunakan sebagai marker untuk obesitas (3), karena leptin merupakan faktor utama yang menentukan regulasi berat badan, metabolisme energi dan terjadinya obesitas serta kelainan yang menyertainya pada manusia (4).

Pada penelitian ini juga menunjukkan bahwa isolat EGCG dengan dosis $50 \mu \mathrm{M}$ dan $100 \mu \mathrm{M}$ menghambat proliferasi sel preadiposit, dengan dosis $100 \mu \mathrm{M}$ mempunyai efek yang paling kuat, hal ini sesuai dengan penelitian yang dilakukan oleh Ratnawati et al bahwa pada dosis EGCG $100 \mu \mathrm{M}$ mampu menurunkan mRNA PPAR $\gamma$, SREBP-1, C/EBP $\alpha$ dan gen TNF $\alpha$ pada sel adiposa viseral manusia (8).

Mekanisme yang mendasari kerja EGCG dalam menghambat adipogenesis menurut Lin et al berkaitan dengan Mitoge-Actvated Protein (MAP) Kinase, terutama Extracellular Signal-Related Kinase (ERKs) (10). Fosforilasi ERK $1 / 2$ meningkatkan ekspresi CEBP $\alpha$ dan PPARy yang keduanya merupakan mediator kunci dari adipogenesis pada kultur sel 3T3-L1, dan hambatan pada ERK $1 / 2$ secara signifikan melemahkan ekspresi C/EBP $\alpha$ dan PPARY. EGCG dapat menghambat fosforilasi dari ERK $1 / 2$ dan AKT kinase pada kultur sel epidermis dan sel mast (13). EGCG terbukti mampu menurunkan phospo-ERK1 dan phospo-ERK2 pada kultur sel preadiposit 3T3-L1, sehingga EGCG diduga 
bekerja menghambat ERK signaling pathway pada adiposit, yang menyebabkan terjadinya hambatan pada lipogenesis. Menurut Hui et al aktifitas EGCG pada sel preadiposit disebabkan oleh adanya reseptor EGCG pada sel preadiposit dan sel adiposit yaitu Laminin Reseptor (67LR), sehingga EGCG dapat menghambat fosforilasi ERK $1 / 2$ melalui hambatan stimulasi insulin yang merupakan salah satu faktor adipogenik yang memicu proses diferensiasi adiposit.

Pada penelitian ini telah terbukti efek anti-obesitas dari isolat EGCG dari teh hijau klon GMB4 yang mampu menghambat proses adipogenesis dengan menurunkan ekspresi protein faktor transkripsi C/EBP $\alpha$ yang merupakan regulator utama adipogenesis dan mampu menurunkan kadar leptin yang merupakan faktor utama yang menentukan regulasi berat badan, metabolisme energi dan terjadinya obesitas pada dosis optimum 200

\section{DAFTAR PUSTAKA}

1. Departemen Kesehatan RI. Laporan Hasil RISKESDAS Nasional. Jakarta: Departemen Kesehatan RI; 2010.

2. Andrew $M$ and Prentice. The Emerging Epidemic of Obesity in Developing Countries. International Journal of Epidemiology. 2006; 35: 93-99.

3. Yang R and Barouch LA. Leptin Signaling and Obesity. Circulation Research. 2004; 101: 545-559.

4. Livshits G, Pantsulaia I, and Gerber LM. Association of Leptin Level With Obesity and Blood Pressure: Possible Common Genetic Variation. International Journal of Obesity. 2005; 29(1): 85-92.

5. He Y, Chen H, Quon MJ, and Reitman M. The Mouse Obese Gene: Genomic Organisation Promoter Activity and Activation By CEPB/ $\alpha$. The Journal of Biological Chemistry. 1995; 9(19): 2350-2363.

6. Miller SG, de Vos P, Guerre-Millo M, et al. The Adipocyte Specific Transcription Factor C/EBP $\alpha$ Modulates Human Ob Gene Expression. Proceedings of the National Academy of Sciences of the United States of America. 1996; 93(11): 5507-4411.

7. Krempler F, Breban D, Oberkofler $\mathrm{H}$, et al. Leptin Peroxidase Proliferator Activated Receptor $\gamma$ and $\mu \mathrm{M}$. Perlu dilakukan penelitian lebih lanjut dengan variasi dosis dan waktu inkubasi, baik secara in vitro maupun in vivo dan variabel-variabel lain yang mendasari kerja dari EGCG yaitu reseptor 67LR dan jalur sinyaling yang berperan terutama ERK $1 / 2$ serta pengaruh isolat EGCG terhadap teh hijau klon GMB4 protein faktor transkripsi dan adiponektin yang lain untuk melengkapi pathway dari EGCG dalam mempengaruhi proses adipogenesis dalam rangka menggali potensi isolat EGCG teh hijau klon GMB4 sebagai agen anti-obesitas.

Berdasarkan hasil penelitian ini dapat disimpulkan bahwa isolat EGCG teh hijau klon GMB4 secara signifikan dapat menurunkan ekspresi protein faktor transkripsi C/EBP $\alpha$ pada kultur preadiposit viseral tikus pada konsentrasi $200 \mu \mathrm{M}$. Isolat EGCG teh hijau klon GMB4 dapat menurunkan kadar protein leptin pada kultur preadiposit viseral tikus pada konsentrasi $50 \mu \mathrm{M}, 100 \mu \mathrm{M}$, dan $200 \mu \mathrm{M}$.

CCAAT/ Enhancer Binding Protein- $\alpha$ mRNA Expression in Adipose Tissue of Humans and Their Relation to Cardiovascular Risk Factors Arterioscler. Arteriosclerosis, Thrombosis, and Vascular Biology. 2000; 20: 443-449

8. Ratnawati R, Indra MR, and Satuman. Green Tea Epigallocatechin Gallate Inhibits Adipogenesis in the Primary Human Visceral Preadipocyte Culture. Majalah IImu Faal Indonesia. 2007; 6(3): 160-164.

9. Mawarti H, Ratnawati R, dan Lyrawati D. Epigallocatechin Gallate Menghambat Resistensi Insulin pada Tikus dengan Diet Tinggi Lemak. Jurnal Kedokteran Brawijaya. 2012; 27(1): 43-50.

10. Indra MR. Dasar Genetik Obesitas Visceral. Jurnal Kedokteran Brawijaya. 2006; 22(1): 10-19.

11. Lin J, Della-Fera MA, and Baile CA. Green Tea Polyphenol Epigallocatechin Gallate Inhibits Adipogenesis and Induce Apoptosis in 3T3-L1 Adipocyte. Obesity Research. 2005; 13(6): 982-990.

12. Musri MM, Gomis R, and Parrizas M. Chromatin and Chromatin Modifying Proteins in Adipogenesis. Biochemistry and Cell Biology. 2007; 85(4): 397-410.

13. Meydani M and Hasan ST. Dietary Polyphenols and Obesity. Nutrients. 2010; 2(7): 737-751. 